\title{
STRENGTHENING PANCASILA AS NATIONAL IDEOLOGY TO IMPLEMENTATE THE BALANCING VALUES TO IMPROVE LAW'S APPLICATION IN INDONESIA
}

\author{
Muhammad Chairul Huda \\ State Institute for Islamic Studies (IAIN), Salatiga \\ choirulhuda4999@gmail.com
}

\begin{abstract}
People's perception of Pancasila seems to be on the way back. It reminds us that the acceptance of Pancasila as the national ideology is actually not something taken for granted. For that reason, it is necessary to refresh the Pancasila from aspects of knowledge, understanding and practice of the philosophical values contained in it. Law development must be started from the values of Pancasila, because essentially Pancasila is a milestone of convergence of ideas and thoughts on the basic philosophy of state discussed deeply by the founders of the state. Pancasila becomes a sublime agreement (modus vivendi) which is then established as the foundation of state ideology. In this case, Pancasila becomes the rational basis of assumptions about the law to be established as well as the orientation that shows where the nation and state should be established. Thus, Pancasila is an agreement and consensus to build a nation of one country, without considering the different backgrounds that include religion, race, ethnicity, culture, language and others. As the foundation of the state, Pancasila becomes the rechtsidee that should be written in every law-making and enforcement.
\end{abstract}

Keyword: Modus vivendi; Pancasila; Rechsidee.

\section{A. INTRODUCTION}

It's surprised the idea of political thought contained in Pancasila is a perfect and solutivecreation. The founders of our country are able to create it very creatively, taking the middle way between the two extremes, the secular state and the religious state. We cannot imagine if the first founding fathers did not find it, then maybe we do not meet in this world a country called Indonesia. They compiled it by imaginative formulation, the state based on the Belief in the One Supreme.

Compared with Turkey, to find a way out of the decline of Utsmani
Dynasty that was in charge for almost eight centuries, Turkey finally chose a secular state marked by the fall of the Khalifah in March 1924. Turkey became the first secular state in the Muslim community. On the other hand, in South Asia, Pakistan, a land which stands on the former Mongol region, from two currents of political thought competing on the way to independence between Ali Jinnah ${ }^{1}$ as

1 Muhammad Ali Jinnah: 25 December 1876-11 September 1948, was a politician and founder of Pakistan. Jinnah was a leader of Indian Muslim League from 1913 until the independence of Pakistan on 14 August 1947, and had position as the first General Governor of Pakistan until he died. In Pakistan he was 
a representation of the idea of a secular state and Maududi ${ }^{2}$ as a representation of the development of religious state ideas, after failing to synergize a solutive format for a modern state.

The founders of our country with great wisdom and genius are able to agree on the right choice of the state base in accordance with the character of the nation, very original, becoming a modern state of religious character, neither as a secular state nor a religious state.

Its conceptual formulation is totally oriented -and in accordance with the character of the nation. They are not only able to remove the influence of the idea of patrimonial state (inheritance) that coloured it throughout the history of pre-colonial archipelago, but also able to concoct a variety of political thinking that developed at that time creatively according to the needs of the future of modern children of the nation.

No wonder if there are many intellectuals or statesmen who praise the monumental achievements of the founders of the Republic of Indonesia.

dubbed Quaid-i-Azam (great leader) and Babai-Qaum (Father of Nation). His birthday was celebrated as nasional holiday of Pakistan. (source: Wikipedia)

2 Abul A'la Maududi: 25 September, 1903 - 22 September, 1979), was a moslem scholar of 20 s century as well as the pioner of Jamaat-eIslami (Islamic party). Maulana Maududi was an expert in philosophy, artist, and activist of Islamic movement and struggle all over the world. Maulana Maududi got mandate from Sayyid Qutb in Egypt namely Jamiat al-Ikhwan al-Muslimun. Like Qutb, Maududi was the figure of Islamic development and Struggle all over the world. (source:Wikipedia)
One of the Saudi Arabia intellectuals and senior officials who once praised Pancasila was Dr. Izzat Mufti when he visited Indonesia in the 1980s, after hearing the explanation of Pancasila at the Satria Mandala Museum, he conveyed an interesting view: "Saudi Arabia makes the Qur'an and Hadith as the basis of the state because all of its citizens are Muslims. The multireligious Indonesia makes Pancasila as the basis of the State in which the first precepts are Belief in the One Supreme. That's the right decision and not against Islam. Pancasila has become the framework of the unity of the Indonesian "3.

During the post-reform period, Pancasila energy is proceeding automatically. Let us consider various kinds of conflicts and unbelievable calamities we can overcome. Compared with Myanmar when happening natural disaster of tsunami and earthquake, Indonesia welcome and received foreign aid, while Myanmar limited itself to fear of foreign interference that inflow aid. Yet at that time Aceh was in a situation of political conflict and many people were worried about the impact of entry of outsiders. However, it was true that peace was realized. During the tsunami disaster, solidarity underlying the precepts of "Indonesian Unity" and the principle of "just and civilized humanity" emerged simultaneously. Humanitarian aid came from all corners of the country helping the people of Aceh without anyone giving command.

3 As'ad Said Ali, 2009, Negara Pancasila Jalan Kemaslahatan Bangsa, LP3ES, Jakarta, p.3 
Pancasila Energy is what emerges and encourages peace in conflict areas. Generally, these conflicts, not least the conflicts in Ambon and Poso, are suspected as part of a political conflict that cannot be separated from the provocation and "subtle" intervention of outsiders. After a period of conflict can be passed, there are deep regrets from both sides.

In celebrations of religiousgreat days, for example, we often encounter Muslim youths like $G P$ Ansor, Banser, Muhammadiyah Youth, etc. to helping the Christians who are celebrating chrismas. This is a phenomenon we rarely see in other countries.

In short, Pancasila must be discussed or dialogued by all elements to become the energy of the unity of the whole nation. The greater the party or component of the nation to understand Pancasila, the greater the energy that is formed to achieve the ideals of the nation and state so that the emission will illuminate the future of the nation and the world. In that context Pancasila needs to get attention, especially its function which not only stops being a commitment together, but it must be understood as the vision of the nation that always strived to be realized as well. Pancasila is the ambition and the signs in carrying out the state.

In principle, Indonesia accepts everything that does not harm the nation and the state. It refers to the rule of jurisprudence that in its original law everything is permitted until there is a proposition that forbids it (Al ashlu fi al asya'i al ibahah hatta yadulla ad dalilu at tahrimi). ${ }^{4}$

In the era of Prophet Muhammad SAW and Al-Khulafaur alRashidin, it is not found conception of a standard state. When there is a succession (leadership shift), there is no appointment system or lineage as a successor to the previous khalifah. Then Medina charter which many political experts claimed to be the first constitution of the Islamic State. It also does not mention the state religion in it. $^{5}$ The Medina Charter is the cornerstone of civilized life for a plural Medina society, containing the values of tolerance, and upholding the human rights of its people in a united frame. The basic substance of the Medina Charter includes:

1) All followers of Islam, though coming from many tribes, but one community.

2) The relationship between fellow members of the Islamic community and members of the community and other communities is based on the principle:

a. Neighborly good

b. Help each other in facing the common enemy

c. Defend the persecuted ones

d. Advice each other

3) Respect freedom of religion. Believe in the One Supreme.

4) Just and civilized humanity

5) Unity of Indonesia

6) The democracy led by understanding wisdom among

4 Syamsul Ma'arif, Kaidah-Kaidah Fiqih, Pustaka Ramadhan, Jakarta, p.19

5 Munawir Sadzali,1990, Islam dan Tata Negara, UI-Press, Jakarta, p.30 
honorable representatives, from the parliament house

7) Social justice for all of the people of Indonesian. ${ }^{6}$

The spirit of Islam in a state can be deduced from the works of the scholars. The general principles that must be implemented in a country are: As-Shuro (consent), Al-'Adl (Justice), Al-Hurriyah (Independence, freedom), and Al-Musowah (egalitarian). ${ }^{7}$

\section{B. DISCUSSION}

\section{THE HISTORY OF PANCASILA}

The term of Pancasila has been known since the era of Sriwijaya and Majapahit where the values contained in the Pancasila has been applied in public life even though its values have not been formulated concretely. The term Pancasila has been known since the era of Majapahit as written in the book of Negara Kertagama by Mpu Prapanca and book of Sutasoma by Mpu Tantular. In the book of Sutasoma by Mpu Tantular, the term Pancasila has the meaning of five rocky joints, the implementation of five principles. The term Pancasila itself comes from Sansekerta, Panca means five and Sila means basic or principle.

The history of Pancasila in the modern era originated from the promise of giving of independence to the nation of Indonesia by the Prime Minister of Japan, namely Kuniaki Koiso on September 7, 1944. From the promise, the Government of Japan then formed what is called Dokuritsu

6 Ibid, p.16

7 Achmad Muhibbin Zuhri, 2010, Pemikiran KH.M. Hasyim Asy'ari, Khalista, Surabaya, p.59-61.
Junbi Cosakai or in Indonesian it is known BPUPK (Badan Pengelidik Usaha-Usaha Persiapan Kemerdekaan) on April 29, 1945. And on March 1, 1945 BPUPK was inaugurated by the Japanese government and led by $\mathrm{Dr}$. Ir. KRT. Radjiman Wedyodiningrat. The establishment of BPUPK aims to carry out the task of investigating matters related to the establishment of an independent Indonesia that is related to political, economic, legal and governance aspects. ${ }^{8}$

BPUPK during preparing Indonesia's independence, held two general assemblies, the first general assembly was held on May 29, 1945 June 1,1945 . And the second general was held on July 10,1945 - July 11 , 1945. In the first general session discussed about matters related to the preparation of independence. One of them is about the basis of an independent Indonesian state. This is a request from the chairman of the session asking the participants of the session to propose about philosofische grondslag or the philosophical foundation of an independent State of Indonesia which will be established.

There are three figures who expressed their opinion about the basis of state, namely Muhammad Yamin, Soepomo and Sukarno. While other members of BPUPK objected to expressing their opinion for they were fear that the talks would be an unconcrete philosophical debate, and

8 Teguh Prasetyo, 2017, Membangun Hukum Berdasarkan Pancasila, Nusamedia, Bandung, p.8 
it would just delay the reality of an independent Indonesia. ${ }^{9}$

a. Speech of Muhammad Yamin (May 29, 1945)

The speech of Muhammad Yamin is entitled Principle and Basis of Republic of Indonesia. In his speech Muhammad Yamin divided into five things:
1) Nationality
2) Humanity
3) Divinity
4) Populist
5) People's welfare

b. Speech of Soepomo (May 30, 1945) In line with the country's basis, Soepomo states that the question of the basis of state was essentially a question of the ideals of the state. Soepomo said that in the formation of the state should be adjusted with legal history and social institutions and history and patterns of Indonesian society are integralistic. Soepomo did not propose the basis of the philosophy of an independent Indonesia, but he proposed the plan an independent Indonesian state, ie a flow or an integralistic idea.

c. Speech of Soekarno (June 1, 1945)

From this Soekarno's speech came the name of Pancasila. So it was often said that Soekarno was the creator of Pancasila. Regarding the basis of an independent Indonesian called as the philosofische Grondslag or weltfanschauung, Sukarno proposed five basic principles:
1) Basis of nationality
2) Basis of internationalism

9 Moh.Hatta, 1977, Pengertian Pancasila, Jakarta, p.9
3) Basis of consensus, representation and consultation

4) Basis of prosperity

5) Basis of divinity. ${ }^{10}$

The three advices from $M$. Yamin, Soepomo and Soekarno discussed it in the BPUPK meeting which then formed a small committee of nine people headed by Soekarno. The committee was often referred to the Nine Committees consisting of national figures that come from the nationalist and Islamic groups. The nine figures of the nation are:

1) Ir. Soekarno

2) Drs. Mohammad Hatta

3) Mr. A A. Maramis

4) Mr. Muhammad Yamin

5) Abikusno Tjokrosujoso

6) Abdul Kahar Muzakir

7) H. Agus Salim

8) Mr. Achmad Soebardjo

9) $\mathrm{KH}$. Wachid Hasyim. ${ }^{11}$

One of results produced by the Nine Committee is the Preamble Draft (opening) of the Constitution. The design of the preamble was then named the Charter of Jakarta by Muhammad Yamin. In the Jakarta Charter, it is also formulated the basis of the state, namely Pancasila which includes:

1)Deity with the obligation to enforce Islamic Shari'ah for its adherents.

2)Just and civilized humanity

3)Unity of Indonesia

4)The democracy led by the wisdom of deliberation among representatives
10 A.M.W.Pranaka, 1985, Sejarah Pemikiran Tentang Pancasila, CSIS, Jakarta, p.31

11 Teguh Prasetyo, Op.cit, p.18 
5)Social justice for all of the people of Indonesia.

However, the formulation of Pancasila in the Jakarta Charter proposed by the Nine Committee receives rejection from the eastern Indonesian delegate, which is regarding the first principle. The rejection was conveyed by Mohammad Hatta in the plenary session of PPKI which then scored out eight words "dengan kewajiban menjalankan syariat Islam bagi pemeluk-pemeluknya" behind the word "divinity". And is replaced by the phrase "The One Supreme".

With the acceptance of the preamble or the preamble of the 1945 Constitution on August 18, 1945, the Pancasila formulation in preamble becomes:

1)Believe in the One Supreme.

2)Just and civilized humanity

3)Unity of Indonesia

4)The democracy led by the wisdom of deliberation among representatives

5)Social justice for all the people of Indonesian

With the enactment of the 1945 Constitution by PPKI on August 18, 1945, Pancasila has also been legally and formally used as the basis of the state.

\section{Pancasila As A Source Of National Philosophy}

According to Mohammad Hatta, the first Principle in Pancasila; Believing in the One God is the guiding principle for Indonesia. This spiritual and ethical principle provides guidance for all of the people and nation of Indonesia. Along with this basic principle, the second one, "Just and civilized humanity" is the first continuation of practice, and so are the third and fourth principles. While the fifth principle, "Social Justice for all of the people of Indonesia", became the ultimate goal of the ideology of Pancasila. ${ }^{12}$

According to Mohammad Hatta, by sticking to this philosophy, the Indonesian government should not deviate from the straight path to the safety of the state and society, the order of the world and the fraternity of nation. By placing the principle of the belief of Supreme God as the first one, the state gets a solid moral foundation. ${ }^{13}$ This is the essence of Hatta's opinion of Pancasila.

A few years before his death, Mohammad Hatta reminded: "In everyday life Pancasila is practiced on the lips only. Not many Indonesians actualized the Pancasila as a belief rooted in their hearts. People forget that the five principles are in series, not separated. Under the guidance of the first principle, the deity of the One Supreme God, the five principles are bound". ${ }^{14}$

Pancasila as the basis of state philosophy as well as the philosophy of life of the Indonesian nation is essentially a systematic value. Therefore, as a foundation of philosophy, the principles of Pancasila are a unified, hierarchical and systematic aspect. It means that Pancasila is a philosophical system. Because it is a system of philosophy,

12 Mohammad Hatta,1960, Demokrasi Kita, Panji Masyarakat, Jakarta,p.7

13 Mohammad Hatta, 1977, Pengertian Pancasila, Idyu Press, Jakarta,p.17-18

14 Ibid, p. 20 
the five principles are not separated and have their own meaning, and they also have the essence of the intact meaning.

Pancasila as the philosophy of the nation and state of the Republic of Indonesia implies that in every aspect of nationality life, society and state must be based on the values of Godhead, Humanity, Unity, Democracy and Justice. The philosophical thinking of the state starts from a view that the state is a communion of human life or social organization in legal life or legal society.

The state founded by humans is based on the nature that human as a citizen of the state. Human is a creature of God Almighty (essence of the first principle). It essentially aims to manifest the dignity of human beings as a civilized creature or a civilized being (the essence of the second principle). To establish an organizational state of human life, it must form the union of the bond of living together as a nation (the essence of the third principle). The realization of unity in a country will create people as a nation that lives in a certain country territory. So in life of the state must be based on the value that people are the origin of state power. It is a necessity that the state should be democratic, the rights and powers of the people must be guaranteed both individually and collectively (the essence of the fourth principle). To achieve the goal of the state as the common goal of all its citizens, then in life the state must realize the guarantee of protection for all its citizens, so to achieve that goal, it must be based on a principle of justice that arises in social life (the essence of the fifth principle). These values are a basic value for the life of statehood, nationality and society. ${ }^{15}$

As a foundation of philosophy, Pancasila obtains a source of value in the context of dynamic journey of cultural history of the nation. The establishment of the source of value embodied in the national philosophy system runs in a long history, involving not only the intellectuals, but also the society. ${ }^{16}$ For the Indonesian nation, Pancasila philosophy is part of the Eastern philosophical system that exudes the value of its superiority. As a system of philosophy of theismreligious, it is proven rationally as follows:

1) Substantially and intrinsically the value of Pancasila is philosophical; eg the nature of a just and civilized humanity, the Godhead of the One Supreme is metaphysical / philosophical.

2) Practically, in the culture of Indonesian society of preindependence, Pancasila value is recognized as a philosophy of life practiced.

3) Formally and constitutionally, the Indonesian nation recognizes Pancasila the base of state of the Republic of Indonesia.

4) Psychologically and culturally, Indonesian nation and culture are equal to any nation and culture. Therefore, the Indonesian nation as well as other nations (Chinese,

15 Kaelan. MS., 2010, Pendidkan Kewarganegaraan, Paradigma, Yogyakarta,p.26

16 Slamet Sutrisno, 2006, Filsafat dan Ideologi Pancasila, Andi, Yogyakarta, p.97. 
Indians, Arabs, and Europeans) inherited the philosophical system in their culture. So Pancasila is a philosophy that is inherited in Indonesian culture.

5) Potentially, Pancasila philosophy will develop with the dynamics of culture; Pancasila philosophy will develop conceptually, rich in conception and literature in quantity and quality. Pancasila philosophy is part of the treasures and philosophy that exist in the literature and modern civilization. ${ }^{17}$

\section{Pancasila's Function As National Ideology}

a. Pancasila as National Ideology

Pancasila as an ideology means that it is a doctrine, idea, theory or science that is believed to be true and becomes life view of Indonesia and guidance in solving the problems faced by society, nation and country of Indonesia. Thus, the ideology of Pancasila is a doctrine, theory or science of ambition of Indonesian which is believed to be truthful and systematically arranged and given guidance with clear implementation.

We recognize three levels of value, the unchanging basic values, the instrumental value as a means of realizing the fundamental value that can change according to circumstances, and the value of praxis in the form of real performance. Nevertheless, the embodiment or the exercise of instrumental values and preclinical values must still contain the same spirit as their basic values.

b. Pancasila as the basis of the State.

Pancasila as the basis of the state implies that Pancasila is used as the foundation to regulate the state government or as a basis for governing the state's administration. Thus, Pancasila is a fundamental rule of the state, which means that both written and unwritten basic laws and all applicable legislation within the state of the Republic of Indonesia must be sourced and under the fundamental principles of the state's rule.

c. Pancasila as the National Life Views

Pancasila in this sense is often called as the grip of life, the guidelines of life, the direction of life and the way of life. As the nation's life view, Pancasila serves as guidance in everyday life. This means Pancasila as a life view is a direction of all activities or activities of life and life in all fields.

d. Pancasila as Personality of Nationality

This means that as like the red and white flags as the distinctive characteristics of the Indonesian nation or state that distinguishes them from other nations or countries, Pancasila is also a hallmark of Indonesian reflected in attitudes, behaviors and deeds that are always in harmony and balance based on the values of Pancasila itself. 


\section{The Equilibrium Values In The Perspective Of Pancasila}

In forming a law by the state, of course it has some goals to be achieved, none of the laws are created without any purpose, and there is a goal to be achieved by law. In point of view of the western theory, the purpose of law begins in ethical theory which explores that the objective of law is solely for the realization of justice. The utilitarian theory promoted by Jeremy Bentham mentions that the purpose of law is to realize Utility, and the legalistic theory explains that the purpose of law is to realize legal certainty.

Legal development must be started from the values of Pancasila, because essentially Pancasila is a milestone of convergence of ideas and thoughts on the basic philosophy of state discussed deeply by the founders of the state. Pancasila becomes a sublime agreement which is then established as the basis of state's ideology. In this case, Pancasila becomes the rational basis of assumptions about the law to be established as well as the orientation that shows where the nation and state should be established.

Thus, Pancasila is an agreement and consensus to build a nation of one country, without seeing the different backgrounds that include religion, race, ethnicity, culture, language and others. As foundation of the state, Pancasila becomes the rechtsidee that should be included in every law-making and enforcement. Notonegoro states that Pancasila becomes a legal law because of its position as the fundamental principle of state which has the power as grundnorm. As a legal law, Pancasila becomes the guide star of all national legal products, which means that all legal products aim at achieving the ideas of Pancasila. The establishment of any system adopted by the Indonesian nation is written in a constitution called the 1945 Constitution, and it is also written in other regulations.

In law No. 12 of 2011 concerning about the Legislation Establishment Rules is described that several sources of written law are determined as follows:

1) 1945 Constitution of the State of the Republic of Indonesia;

2)The Decree of the People Consultative Assembly;

3)Law / Regulation in Lieu of Law;

4)Governmental Regulation;

5)Presidential Regulation;

6)Provincial Regulations; and 7)Regency / City Regulation.

In its definition, some experts define the law extensively. There is no clear limitation of legal terminology. The notion of law can be seen from various understandings such as sociological, realist, anthropological, historical, natural law and also positivist law.

Currently, Indonesia has a legal system that must be obeyed by every individual without exception. In Article 1 paragraph 3 of the 1945 Constitution states "The State of Indonesia is a State of law" (UUD, 1945: 6). Therefore, everyone is guaranteed all their rights attached to them, both in the form of written and unwritten law. Indonesia is dominant in the legal system that we embrace, namely continental European system, which claims that the main source of 
law is the Law, which is arranged systematically. Indonesia claims that Pancasila is the ideology of the nation. So in the formation of legal products we always refer to Pancasila as its source. Pancasila contains the dimension of normality which means that Pancasila contains values that must be obeyed. In this matter, the norm specified in this case is the legal norm. And it is of course a positive law. In Indonesia positive law can be a Constitution, Law, Government Regulation, Presidential Regulation and also Local Regulation. All of these are written laws.

The decision of Pancasila as the legal source of all legal sources of the State is based on the preamble of the 1945 Constitution which positions Pancasila as the foundation and ideology as well as the philosophical foundation of the nation and the State. So material on legislation is not contrary to the value contained in Pancasila. From the explanation above, the existence of Pancasila for the law is fundamental principle in the formation of legislation. And it is applied to all society as a legal subject.

The law here can be described as the lady of justice, the values contained therein are equality with closed-eye image as if the law does not distinguish one person from another based on religion, tribe, class and economic status. Furthermore, the scale for consideration is that the law must consider both parties in dispute by considering the evidence available. The last picture is law enforcement which is symbolized by the sword; the law is applied with legitimate power.
Therefore, the law must be based on equality, consideration and implementation. Without these three factors our law will not prevail, and it is only as Law in the bookshelf.

Each principle of Pancasila is also written in the preamble of 1945 Constitution of the 4th paragraph which says:

"Pursuant to which, in order to form Government of the state of Indonesia that shall protect the whole people of Indonesia and the entire homeland of Indonesia, and in order to advance general prosperity, to develop the nation's intellectual life, and to contribute to the implementation of a world order based on freedom, lasting peace and social justice, Indonesia's National Independence shall be laid down in a Constitution of the State of Indonesia, which is to be established as the State of Republic of Indonesia with sovereignty of the people and based on the belief in the one and only god, on just and civilized humanity, on the humanity of Indonesia and on democratic rule that is guided by the strength of wisdom resulting from deliberation/representation, so as to realize social justice for all the people of Indonesia".

Basically, the formation of a law or other regulation aims to regulate the behavior of the community in interconnection among the members of other community, so it is expected to guarantee a legal certainty. The concept embodied in the opening of the 1945 Constitution of the 4th alenia in the phrase: "... establishing a government that protects the entire nation of Indonesia and the whole of Indonesia's blood 
spill ..." can be fulfilled, but in its application there are still many obstacles and problems.

The formulation contained in the fourth paragraph of preamble of the 1945 Constitution is very complex. It means that the formula is adequately used as the foundation to form a system that is able to reach various aspects contained within the state of Indonesia. From that case, the concept of Pancasila implied in the opening of the 1945 Constitution is the national goal of the Indonesian nation, which consists of:

1) Establishing a government that protects the entire nation and the entire blood of Indonesia

2) Promoting the common prosperity and educating the nation

3) Implementing world order.

4) The State of Indonesia has the basic philosophy of Pancasila namely; believe in the One Supreme. Just and civilized humanity, Unity of Indonesia, The democracy led by understanding wisdom among honorable representatives, from the parliament house, and Social justice for all the people of Indonesian

Article 1 Paragraph 2 of 1945 Constitution of the amendment states "sovereignty is in the hands of the people and carried out according to the law". and in paragraph (3) it says "the state of Indonesia is a state of law" so that the people in this case are those who have the main role in to implement national goals, but legislation rules and underlies its application.

The existence of Pancasila in law is a milestone of achievement in a circle of the State of law. Without Pancasila, there will be legal problems and the creation of unstructured legal construction. It is because Pancasila became a fundamental construction in its formation although some grups judge that Pancasila cannot follow the development of era. There are some who argue that Pancasila is no longer relevant for it cannot follow the development of era, science and technology, but from the dimension of flexibility owned by Pancasila, the issue can be answered. Looking at the history in Indonesia, Pancasila is increasingly relevant to be implemented, especially Pacasila which is related to law. The legal system of Pancasila is the rule of law of Indonesia. Introduction to the Indonesian legal system is the same as that of the Pancasila law. Therefore Pancasila is a written law in Indonesia, a law that lives and is aspired by the nation of Indonesia, law that recognizes God Almighty, the just and civilized humanity, the unity of Indonesia, democracy and the social justice for all of the people of Indonesia.

\section{CONCLUSION}

Pancasila as the foundation of the state has the values of the balance of law, namely religious moral, humanity, and social values (nationalism and social justice).

1. Religious Moral

The concept of Godhead is intended that the law political direction must contain the values of the universality and divine attributes namely; the values of justice, equality, freedom, truth, compassion, protection, togetherness, honesty, trust, 
responsibility, openness, balance, peace and some another permanent values.

2. Humanism

The concept of humanity is intended that the law political direction should be able to position humans as permanent human beings who have basic rights, namely; the right to life, the right to education, the right to work, the right to association, the right to family, the right to happiness, the right to think, to behave and to develop the potential.

3. Nationalism and social justice
This social value is a necessity of the role for the country in all process of life of nation and state. However, the role of state is not for the state itself, but is intended for the welfare of society based on the principle of justice.

From the elaboration above, it can be concluded that Pancasila became a universal and comprehensive state ideology containing the relation of hablumminallah, hablumminannas, and hablu minal alam to achieve the purpose of rahmatan lil alamin.

\section{BIBLIOGRAPHY}

Achmad Muhibbin Zuhri, 2010, Pemikiran KH.M. Hasyim Asy'ari, Khalista, Surabaya.

A.M.W.Pranaka, 1985, Sejarah Pemikiran Tentang Pancasila, CSIS, Jakarta.

As'ad Said Ali, 2009, Negara Pancasila Jalan Kemaslahatan Bangsa, LP3ES, Jakarta.

Kaelan. MS., 2010, Pendidikan Kewarganegaraan, Paradigma, Yogyakarta.

Munawir Sadzali, M.A., 1990, Islam dan Tata Negara, UI-Press, Jakarta.

Mohammad Hatta, 1960, Demokrasi Kita, Panji Masyarakat, Jakarta.

Mohammad Hatta, 1977, Pengertian Pancasila, Idyu Press, Jakarta.

Slamet Sutrisno, 2006, Filsafat dan Ideologi Pancasila, Andi, Yogyakarta.

Syamsul Ma'arif, Kaidah-Kaidah Fiqih, Pustaka Ramadhan, Jakarta.

Teguh Prasetyo, 2017, Membangun Hukum Berdasarkan Pancasila, Nusamedia, Bandung. 